\title{
KARAKTERISTIK SEISMIK KAWASAN KULONPROGO BAGIAN UTARA
}

\section{(THE SEISMIC CHARACTERISTICS OF NORTHERN PART OF KULONPROGO)}

\author{
Bambang Ruwanto, Yosaphat Sumardi, dan Denny Darmawan
}

Fakultas Ilmu Pengetahuan dan Matematika Universitas Negeri Yogyakarta J1. Colombo No. 1 Yogyakarta

E-mail: ruwantobambang@gmail.com

\begin{abstract}
Abstrak
Telah dilakukan pengukuran sinyal mikrotremor di kawasan Kulonprogo bagian utara untuk mendapatkan karakteristik seismik berupa: frekuensi predominan, faktor amplifikasi, ketebalan sedimen, indeks kerentanan seismik, percepatan getaran tanah maksimum, dan nilai pergeseran tanah. Pengukuran dilakukan di 18 titik yang tersebar pada area dengan koordinat geografis $110,10^{\circ} \mathrm{BT}-110,27^{\circ} \mathrm{BT}$ dan $7,64^{\circ} \mathrm{LS}-7,80^{\circ} \mathrm{LS}$. Data yang diperoleh diolah dengan menggunakan metode HVSR (Horizontal to Vertical Spectral Ratio). Hasil yang diperoleh menunjukkan bahwa frekuensi predominan berada pada kisaran nilai 2,98-13,53 Hz; faktor amplifikasi berada pada kisaran 1,6-10,1; ketebalan sedimen berada pada kisaran 5-60 m; indeks kerentanan seismik berada pada kisaran $0,6 \times 10^{-6}-5,8 \times 10^{-6} \mathrm{~s}^{2} / \mathrm{cm}$; nilai percepatan getaran tanah maksimum berada pada kisaran 24-54 gal dan nilai pergeseran tanah berada pada kisaran $0,6 \times 10^{-4}-4,4 \times 10^{-4}$.
\end{abstract}

Kata kunci: seismik, sinyal mikrotremor, Kulonprogo

\begin{abstract}
Microtremor signal measurements had been conducted in the northern part of Kulonprogro to obtain the seismic characteristics in the form of: the predominant frequency value, amplification factor, sediment thickness, seismic vulnerability index, the maximum ground vibration acceleration, and the ground shear strain value. The measurement was conducted at 18 points within geographical coordinates of $110.10^{\circ} \mathrm{E}-110.27^{\circ} \mathrm{E}$ and $7.64^{\circ} \mathrm{S}-7.80^{\circ} \mathrm{S}$. The signals were analyzed using Horizontal to Vertical Spectral Ratio (HVSR) method. The results show that the predominant frequency value is in the range of 2.98-13.53 Hz; amplification factor is in the range of 1.6-10.1; sediment thickness is in the range of 5-60 m; seismic vulnerability index is in the range of $0.6 \times 10^{-6}-5.8 \times 10^{-6} \mathrm{~s}^{2} / \mathrm{cm}$; maximum ground acceleration is in the range of 24-54 gal and ground shear strain value is in the range of $0.6 \times 10^{-4}-4.4 \times 10^{-4}$.
\end{abstract}

Keywords: seismic, microtremor signal, Kulonprogo 


\section{PENDAHULUAN}

Daerah 1stimewa Yogyakarta (DIY) disamping sangat rawan gempa bumi akibat aktivitas tumbukan lempeng di Samudera Indonesia juga sangat rawan gempa bumi akibat aktivitas sesar-sesar aktif di daratan. Beberapa sistem sesar yang diduga masih aktif adalah Sesar Opak, Sesar Oya, Sesar Dengkeng, Sesar Progo, dan sesar mikro lainnya yang belum teridentifikasi (Wagner, 2007). Hal ini menyebabkan tidak hanya gempa bumi yang berkekuatan besar yang terjadi, tetapi juga banyak gempa bumi berkekuatan kecil juga melanda wilayah DIY.

Kulonprogo merupakan salah satu kabupaten di wilayah DIY yang memiliki potensi bencana alam. Longsor (londslide) merupakan salah satu bencana alam yang paling dominanterjadidiwilayah Kulonprogo. Longsor dapat terjadi selain dikarenakan faktor fisiografis dan geomorfologi, juga dapat dipicu adanya gempa bumi yang terjadi di sekitar wilayah tersebut.

Berdasarkan data BPBD Kulonprogo Tahun 2014, terdapat 160 titik lokasi longsor yang tersebar di Kecamatan Girimulyo, Kokap, Pengasih, Kalibawang, Samigaluh, dan Sentolo. Selain longsor, Kabupaten Kulonprogo memiliki potensi bahaya seismik yang berasal dari aktivitas subduksi lempeng Eurasia dan Indoaustralia di wilayah selatan kabupaten tersebut. Potensi bahaya seismik juga dapat berasal dari jalur-jalur sesar yang terdapat di sepanjang perbukitan Menoreh (Kabupaten Kulonprogo bagian utara). Namun, penelitian kebencanaan dengan menggunakan pendekatan potensi bahaya seismik di Kabupaten Kulonprogo masih terbatas, sehingga perlu dilakukan penelitian mengenai karakteristik seismik Kabupaten Kulonprogo terutama kawasan bagian utara.

Penelitian ini bertujuan untuk mengetahui nilai frekuensi predominan, amplifikasi, ketebalan sedimen, nilai indeks kerentanan seismik dan percepatan getaran tanah maksirnurn (peak ground acceleration, PGA) di wilayah Kabupaten Kulonprogo dengan pendekatan rnikrotremor. Penelitian juga bertujuan untuk mengetahui nilai pergeseran tanah (ground shear strain) dan fenomena gerakan tanah yang ada di wilayah Kabupaten Kulonprogo.

\section{METODE PENELITIAN}

Penelitian karakteristik resiko bahaya seismik dengan pendekatan mikrotrernor dilaksanakan di Kabupaten Kulonprogo bagian utara. Dalam penelitian ini digunakan 18 titik pengukuran yang tersebar pada area dengan koordinat geografis $110,10^{\circ}$ BT-110,27 BT dan $7,64^{\circ}$ LS-7,80 LS dengan jarak antar titik sebesar $4 \mathrm{~km}$. Sinyal mikrotrernor diukur dengan Seismograf TDS303 selama \pm 30 menit mengacu pada aturan SESAME European Research Project 
[SESAME] (2004). Data hasil pengukuran kemudian diolah menggunakan metode HVSR (Horizontal to Vertical Spectral Ratio) dengan bantuan software Sessaray Geopsy untuk mendapatkan frekuensi predominan $f_{o}$ dan faktor amplifikasi $A$. Ketebalan sedimen ditentukan dari persamaan (Nakamura, 2000):

$$
H=v_{s} /\left(4 f_{0}\right)
$$

dengan $v_{s}$ adalah kecepatan gelombang $S$ yang diperoleh dari data Vs30 USGS. Nilai indeks kerentanan seismik diperoleh dari persamaan (Nakamura, 1997):

$$
K_{g}=\left(\frac{A}{f_{0}}\right) /\left(4 \pi^{2} V_{S}\right)
$$

sedangkan percepatan getaran tanah maksimum dihitung dengan metode Kanai (Kanai, 1961):

$a_{g}=\frac{5}{\sqrt{T_{0}}} 10^{0,61 M-\left(1,66+\frac{3,6}{R}\right) \log R+0,167-\frac{1,88}{R}}$

dengan $T_{0}$ adalah periode predominan $1 / f_{0}$, $M$ adalah magnitudo gempa dan $R$ adalah jarak hiposenter. Nilai pergeseran tanah $g$ diperoleh dari:

$$
\gamma=K_{g} a_{g}
$$

\section{HASIL DAN PEMBAHASAN}

Nilai karakteristik seismik yang diperoleh dari metode HVSR dan dari
Persamaan (1) sampai Persamaan (4) untuk setiap titik pengukuran kemudian diolah untuk mendapatkan mikrozonasi karakteristik mikroseismik di kawasan Kabupaten Kulonprogo utara. Hasil mikrozonasi akan menunjukkan bagaimana sebaran karakteristik mikroseismik di setiap lokasi pengambilan data. Dari hasil mikrozonasi ini interpretasi data dapat dilakukan dengan lebih mudah. Mikrozonasi pertama yang dihasilkan adalah mikrozonasi frekuensi predominan yang ditunjukkan pada Gambar 1.

Pada Gambar 1 tampak bahwa kisaran nilai frekuensi predominan cukup lebar, yaitu 2,98-13,53 $\mathrm{Hz}$ dengan nilai tinggi mengumpul di titik 6 yang berada di selatan Samigaluh dan titik 18 yang berada di daerah Nanggulan bagian selatan. Nilai frekuensi predominan tinggi biasa dijumpai di daerah dengan karakteristik tanah keras. Frekuensi predominan untuk titik yang lain didominasi oleh nilai rendah yang umum ditemukan untuk tanah lunak dalam bentuk sedimen, seperti yang terlihat pada daerah Girimulyo bagian barat dan Kalibawang bagian timur dan utara. Menurut Elnashai (2008, p. 27), struktur batuan menghasilkan tipe getaran periode pendek (frekuensi tinggi), sedangkan tanah lunak menghasilkan periode yang lebih panjang (frekuesi rendah). Hasil mikrozonasi frekuensi predominan ini juga didukung oleh hasil mikrozonasi 


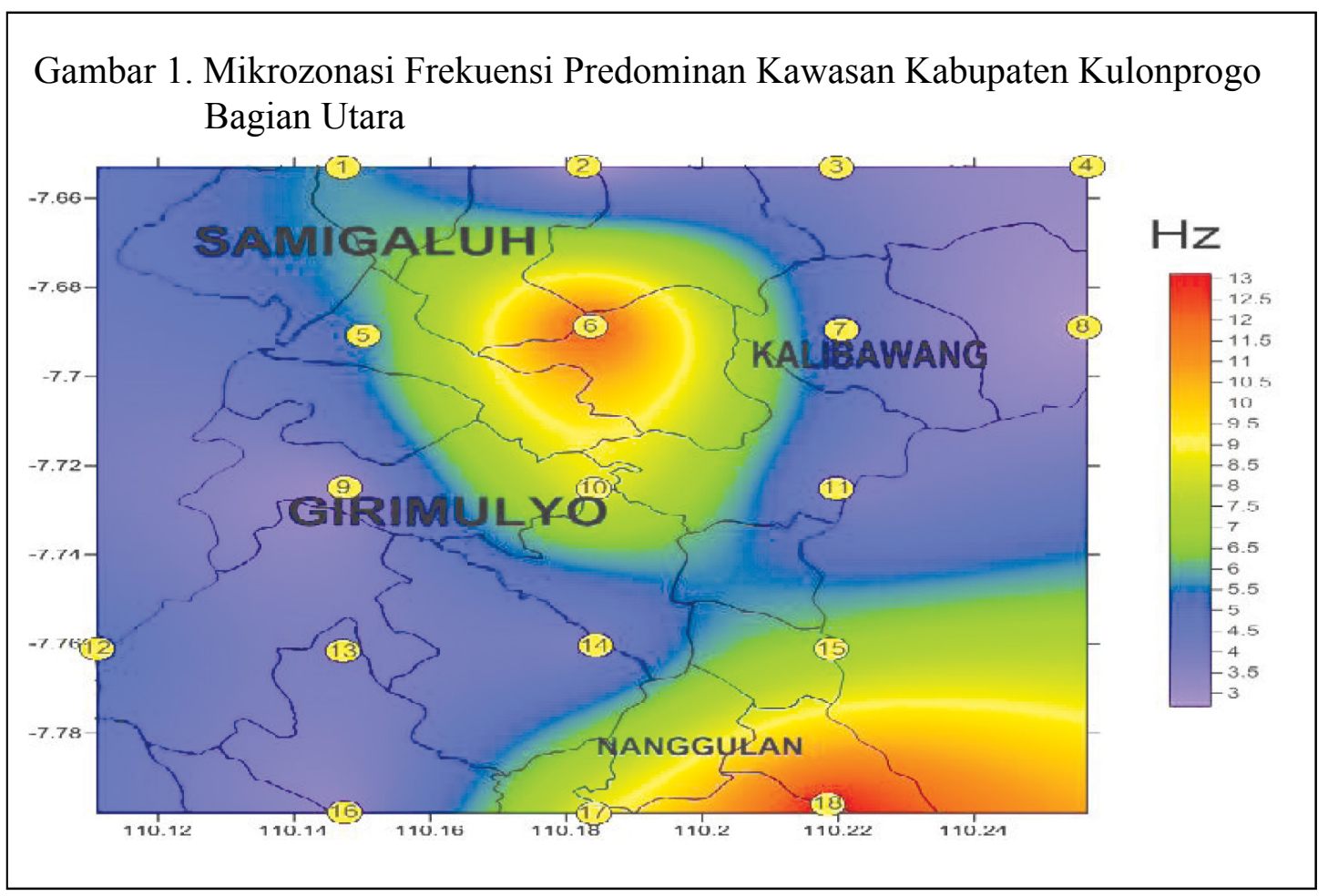

amplifikasi yang ditunjukkan pada Gambar 2. Faktor amplifikasi yang diperoleh dari penelitian berkisar pada nilai 1,6-10,1.

Pada Gambar 2 tampak bahwa daerah Girimulyo dan Nanggulan memiliki faktor amplifikasi rendah yang sesuai dengan hasil mikrozonasi frekuensi predominan (Gambar 1) yang menunjukkan nilai tinggi. Hasil ini menunjukkan bahwa kemampuan lokasi tersebut untuk menguatkan gelombang gempa tidak terlalu besar, yang merupakan ciri dari daerah dengan tanah keras. Daerah dengan faktor amplifikasi besar pada Gambar 2 dimiliki pada daerah Samigaluh bagian utara dan Kalibawang bagian timur. Hasil ini memberikan informasi bahwa kawasan Kabupaten Kulonprogo bagian utara yang berbatasan dengan Jawa Tengah cenderung menguatkan gelombang gempa yang melewatinya dengan faktor penguatan yang cukup besar.

Berdasarkan mikrozonasi frekuensi predominan dan data $v_{s}$, selanjutnya dapat dibangkitkan mikrozonasi dari ketebalan sedimen dengan menggunakan Persamaan (1) seperti ditunjukkan pada Gambar 3. Ketebalan sedimen berkisar pada nilai 5-60 m.

Berdasarkan Gambar 3 tampak bahwa titik 2 merupakan daerah dengan ketebalan sedimen paling besar. Hal ini menunjukkan bahwa lokasi ini berpotensi menguatkan gempa lebih besar, sehingga menjadi daerah yang harus diwaspadai. Meskipun demikian, 
Gambar 2. Mikrozonasi Amplifikasi untuk Kawasan Kabupaten Kulonprogo Bagian Utara
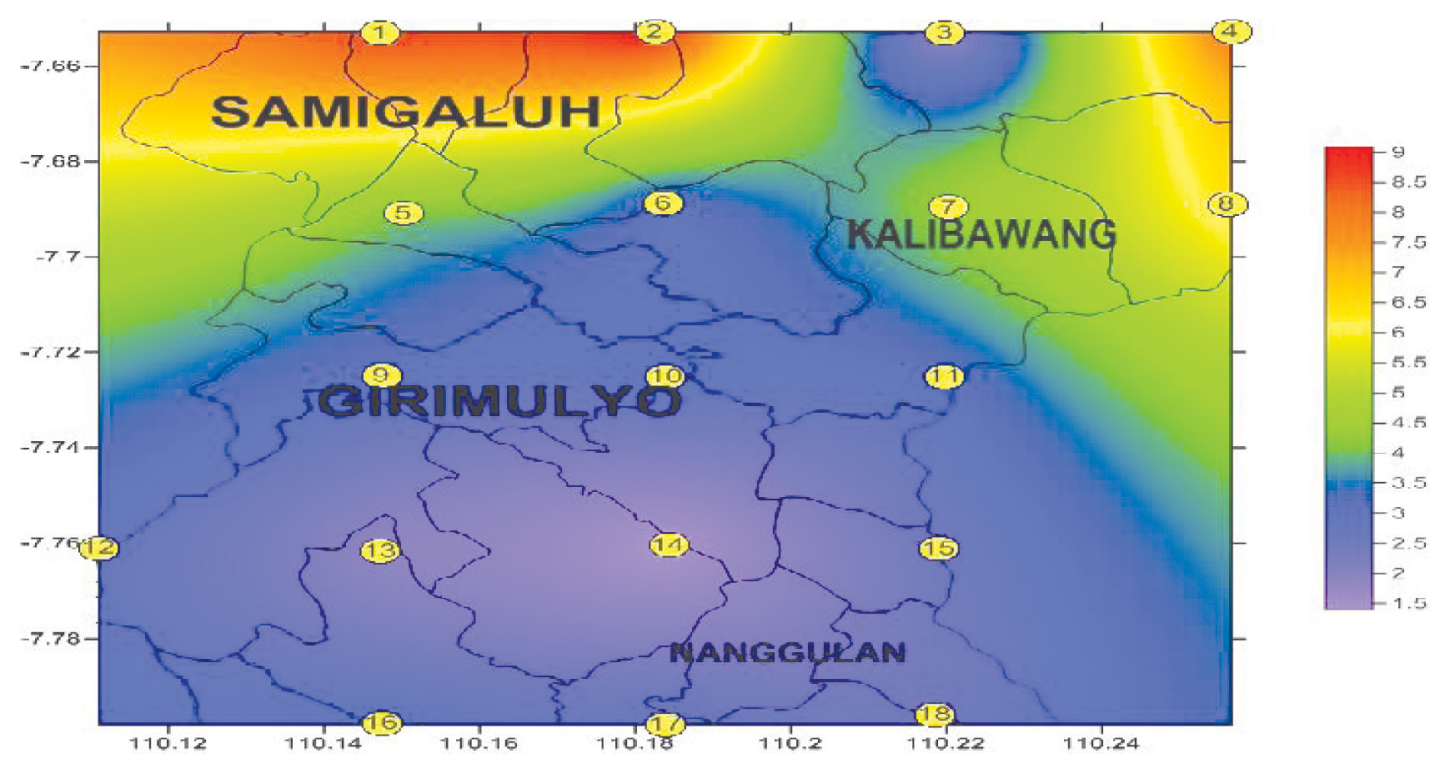

Gambar 3. Mikrozonasi Ketebalan Sedimen untuk Kawasan Kabupaten Kulonprogo Bagian Utara

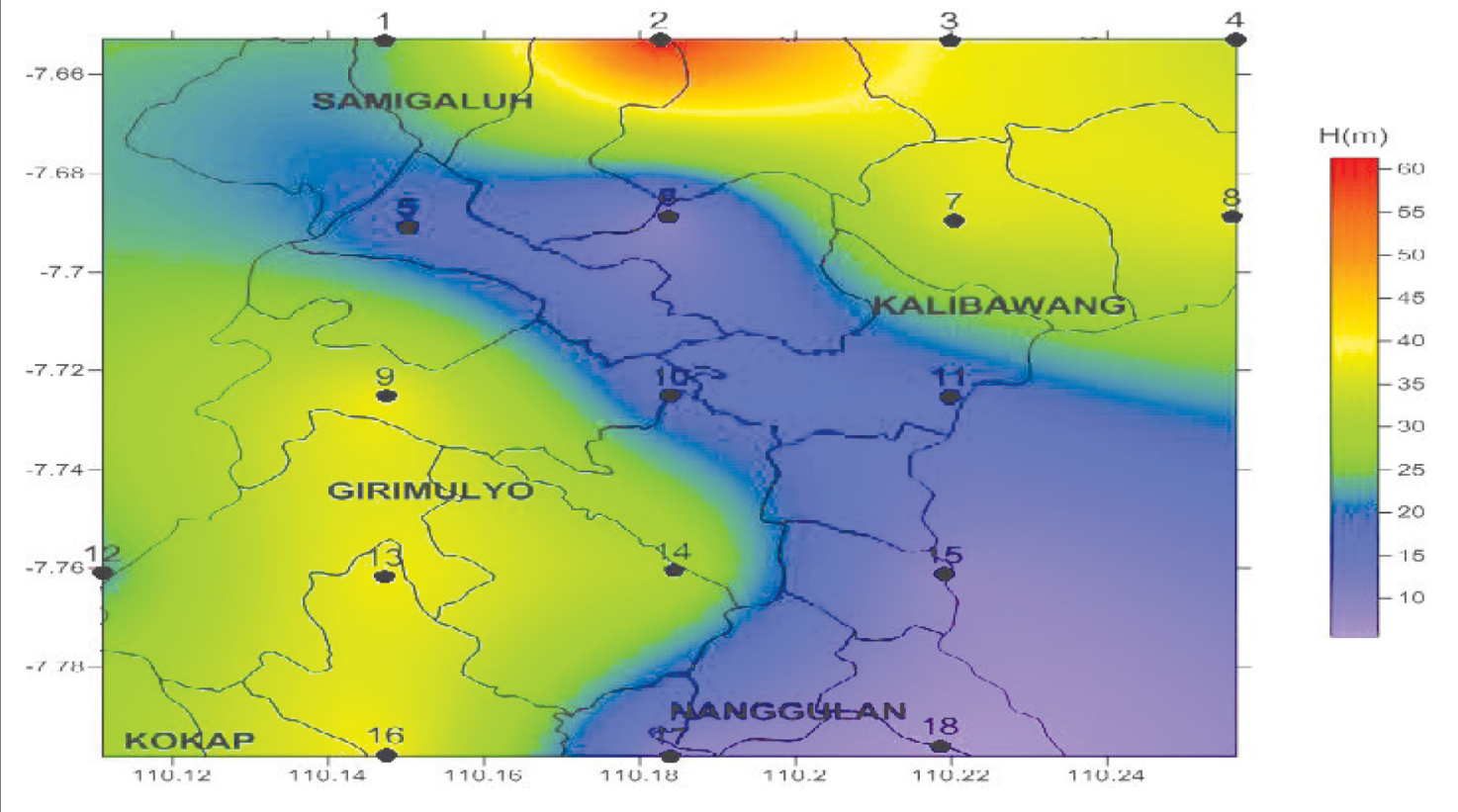


belum diperoleh data bor untuk wilayah ini sehingga hasil penelitian untuk ketebalan sedimen belum bisa dibandingkan dengan data geologi.

Berdasarkan data frekuensi predominan dan amplifikasi dapat dihitung nilai indeks kerentanan $\left(K_{g}\right)$. Indeks kerentanan menyatakan seberapa rentan suatu lokasi mengalami kerusakan ketika dilewati gempa. Tentu saja kekuatan bangunan juga akan menjadi faktor penentu suatu lokasi menjadi daerah yang rentan atau tidak, namun indeks kerentanan lebih ditinjau dari karakteristik tanah di suatu lokasi. Dalam penelitian diperoleh nilai indeks kerentanan seismik berada pada kisaran $0,6 \times 10^{-6}-5,8 \times 10^{-6} \mathrm{~s}^{2} /$ cm. Mikrozonasi nilai indeks kerentanan untuk kawasan penelitian ditunjukkan pada Gambar 4.

Berdasarkan Gambar 4 tampak bahwa daerah Samigaluh bagian utara dan daerah Kalibawang bagian timur merupakan daerah dengan nilai indeks kerentanan yang relatif tinggi. Hal ini berarti daerah ini merupakan daerah yang harus diwaspadai, karena menjadi daerah yang paling rentan terhadap gempa jika ditinjau dari karakteristik ranahnya. Berdasarkan nilai indeks kerentanan juga terlihat bahwa daerah Girimulyo dan Nanggulan me-miliki nilai indeks kerentanan yang lebih kecil sehingga daerah ini menjadi daerah yang relatif lebih aman jika di lihat dari karakteristik tanahnya.

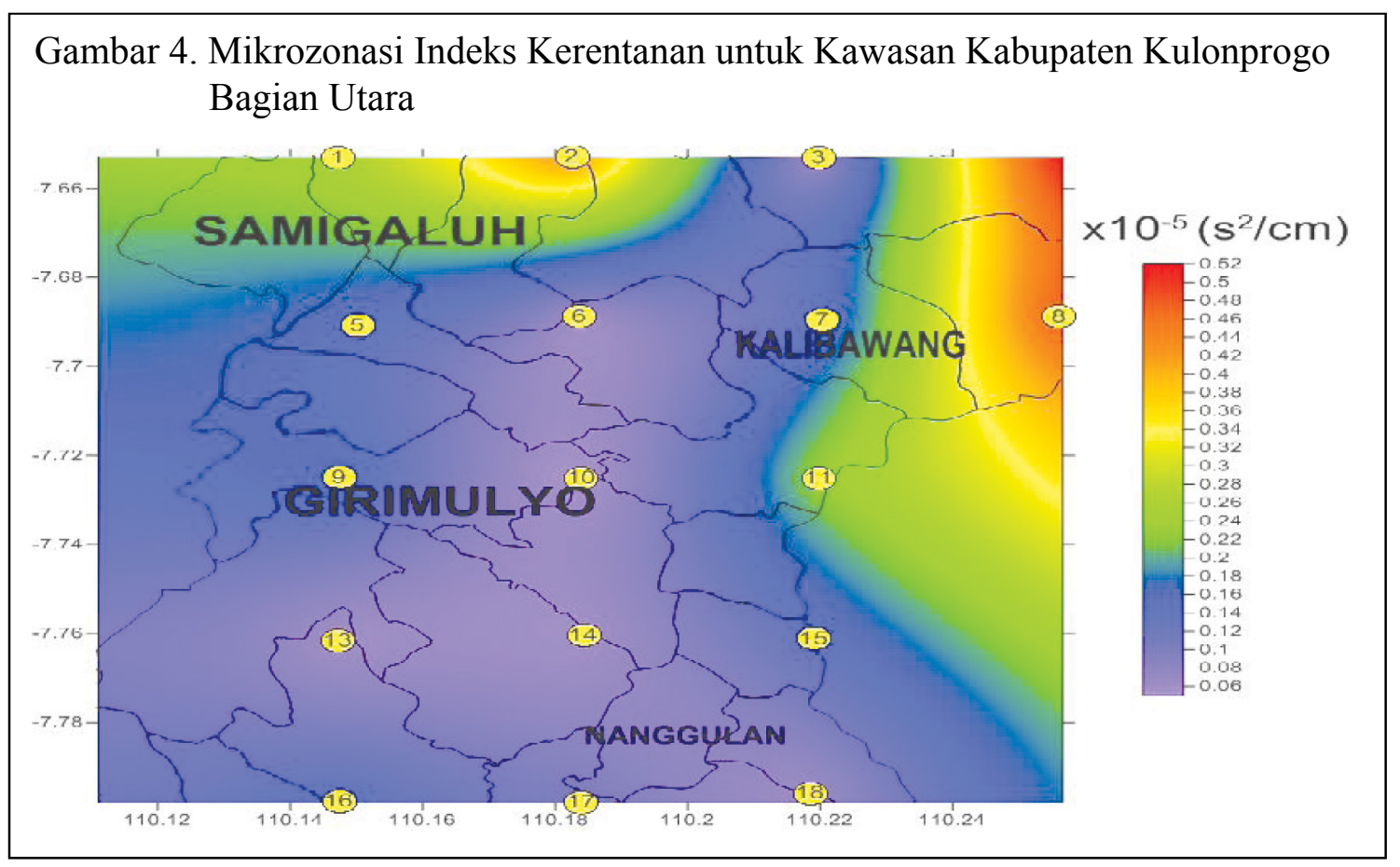


Selain ditentukan dari nilai indeks kerentanan, bagaimana tanah merespon gelombang gempa juga dapat ditentukan dari nilai PGA (Peak Ground Accelerations). Nilai ini menyatakan besarnya percepatan maksimum tanah (perubahan kecepatan dari kondisi diam) ketika suatu lokasi dilewati gelombang gempa. Dalam penelitian ini, nilai PGA ditentukan dari frekuensi predominan dengan menggunakan metode Kanai dan diperoleh nilai pada kisaran 24-54 gal. Mikrozonasi nilai PGA pada kawasan Kulonprogo utara ditunjukkan pada Gambar 5.

Berdasarkan Gambar 5 tampak bah-wa daerah Samigaluh bagian utara dan daerah Kalibawang memiliki nilai PGA yang relatif lebih rendah dibandingkan daerah lain pada lokasi penelitian. Hal ini menunjukkan bahwa daerah ini merespon lebih lambat gelombang gempa yang melewatinya dibanding daerah dengan nilai PGA yang besar. Jika dibandingkan dengan Gambar 3 yang menunjukkan mikrozonasi sedimen, maka tampak bahwa daerah yang memiliki karakteristik tanah lunak cenderung merespon gelombang gempa lebih lambat dibanding daerah dengan tanah keras (daerah di antara Samigaluh dan Girimulyo serta Nanggulan).

Salah satu karakteristik tanah yang terkait dengan aktivitas gempa adalah nilai Ground Shear Strain. Nilai Ground Shear Strain ini menyatakan kemampuan lapisan

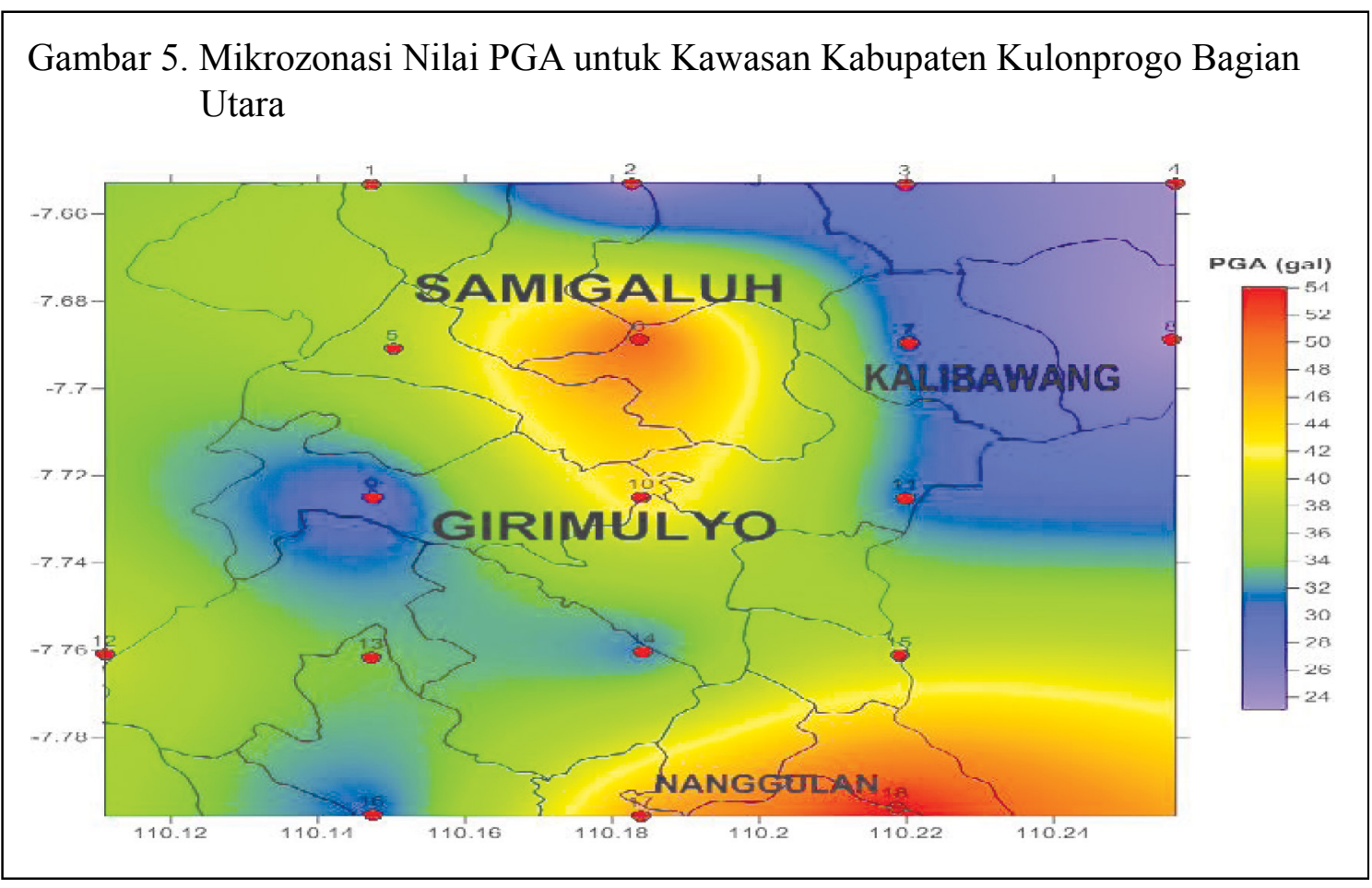


tanah untuk meregang dan menggeser jika dilewati gelombang gempa. Semakin besar nilai Ground Shear Strain di suatu daerah, maka semakin rawan terjadi pergerakan tanah di daerah tersebut. Nilai ini diperoleh dari nilai indeks kerentanan dan nilai PGA. Dalam penelitian ini diperoleh nilai Ground

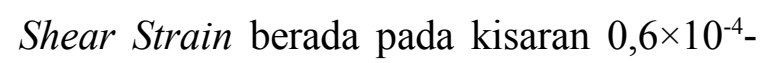
$4,4 \times 10^{-4}$, hasil mikrozonasinya ditunjukkan pada Gambar 6.

Gambar 6 menunjukkan bahwa daerah Samigaluh bagian utara dan Kalibawang bagian timur memiliki nilai Ground Shear Strain yang lebih tinggi dibandingkan daerah lainnya. Hal ini menunjukkan bahwa daerah ini rentan mengalami pergerakan tanah jika dilewati gelombang gempa, terutama jika terdapat kemiringan permukaan tanah yang cukup besar. Pada Gambar 6 juga tampak bahwa daerah Girimulyo memiliki nilai Ground Shear Strain yang relatif lebih rendah dibandingkan daerah lainnya, sehingga peluang terjadinya pergerakan tanah jika dilewati gelombang gempa lebih kecil.

Berdasarkan kelima karakteristik mikroseismik tanah di wilayah Kabupaten Kulonprogo bagian utara (frekuensi predominan, faktor amplifikasi, indeks kerentanan, percepatan tanah maksimum, dan nilai pergeseran tanah), maka dapat diperoleh informasi bahwa daerah Samigaluh bagian utara dan Kalibawang bagian timur merupakan daerah yang patut diwaspadai ketika terjadi gempa bumi.

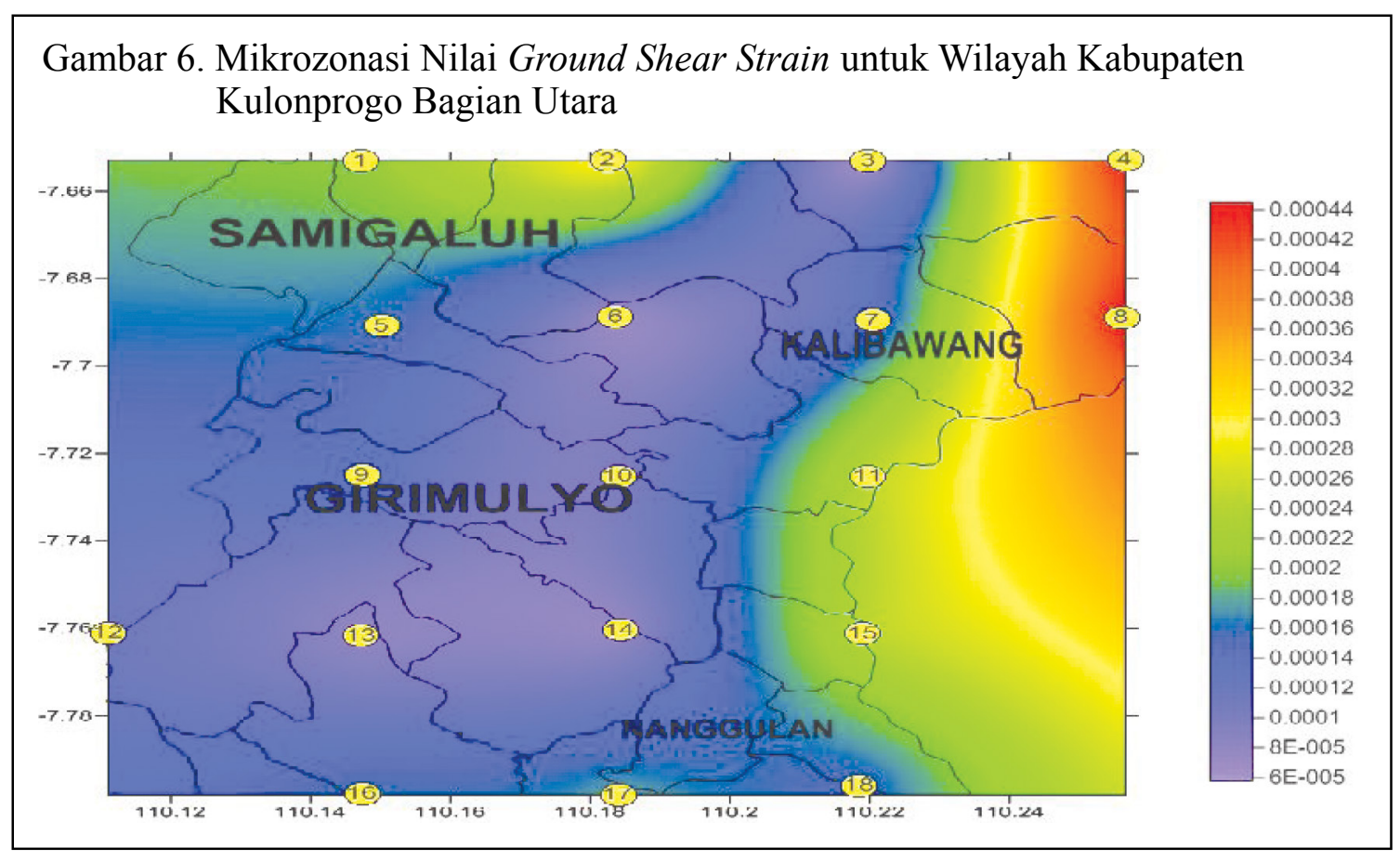


Jurnal Penelitian Saintek, Vol. 21, Nomor 1, April 2016

\section{SIMPULAN}

Berdasarkan hasil penelitian dapat disimpulkan bahwa frekuensi predominan kawasan Kabupaten Kulonprogo bagian utara berada pada kisaran 2,98-13,53 Hz. dengan nilai relatif tinggi diperoleh di daerah Samigaluh bagian selatan dan Nanggulan bagian selatan. Nilai relatif rendah diperoleh di daerah Girimulyo bagian barat dan selatan serta Kalibawang bagian utara dan timur. Faktor amplifikasi berada pada kisaran 1,6-10,1 dengan nilai relatif tinggi diperoleh di daerah Samigaluh bagian utara dan Kalibawang bagian timur, sedangkan nilai relatif rendah diperoleh di daerah Girimulyo bagian selatan. Ketebalan sedimen berada pada kisaran 5-60 $\mathrm{m}$ dengan nilai relatif besar diperoleh di daerah Samigaluh bagian timur laut, sedangkan nilai relatif kecil diperoleh di daerah Nanggulan.

Nilai indeks kerentanan kawasan Kulonprogo bagian utara berada pada kisaran $0,6 \times 10^{-6}-5,8 \times 10^{-6} \mathrm{~s}^{2} / \mathrm{cm}$ dengan nilai relatif tinggi diperoleh di daerah Kalibawang bagian timur. Nilai relatif rendah diperoleh di daerah Girimulyo dan Nanggulan. Nilai percepatan getaran tanah maksimum berada pada kisaran 24-54 gal dengan nilai relatif besar diperoleh di daerah Girimulyo bagian selatan dan daerah Nanggulan, nilai relatif kecil berada di daerah Kalibawang bagian timur. Nilai pergeseran tanah berada pada kisaran $0,6 \times 10^{-4}-4,4 \times 10^{-4}$ dengan nilai relatif besar diperoleh di daerah Kalibawang bagian timur, sedangkan nilai relatif kecil diperoleh di daerah Girimulyo bagian selatan.

\section{DAFTAR PUSTAKA}

Badan Penanggulangan Bencana Daerah. (2014). Data Bencana Kabupaten Kulonprogo.

Elnashai, A. S., \& Sarno, L.D. (2008). Fundamentals of Earthquake Enginering. United Kingdom: John Wiley \& Sons, Ltd.

Kanai, K., \& Tanaka, T. (1961). On microtremors VIII. Bulletin Earthquake Res. Inst. Univ. Tokyo, 39, 97-114.

Nakamura, Y. (1997). Seismic vulnerability indices for ground and structures using microtremor. Florence: World Congress on Railway Research.

Nakamura, Y. (2000, Januari). Clear identification of fundamental idea of Nakamura's technique and its applications. In Proceedings of the $12^{\text {th }}$ World Conference on Earthquake Engineering (Vol. 2656). New Zealand: Auckland.

SESAME, W. (2004). Guidelines for the implementation of the $H / V$ spectral ratio technique on ambient vibrationsMeasurements, processing and interpretation. SESAME European research project, Deliverable D23. 12., Project No. EVG1-CT-2000-00026 SESAME, 62 pp.

Wagner, D., Koulakov, R., Rabbel, W., Luehr, B.G., Wittwer, A., Kopp, H., ... and the Meramex Scientists. (2007). Joint inversion of active and passive seismic data in Central Java, Geophys. J Int., 170, 923-932. 